\title{
Pengembangan Sistem Informasi Obat Berdasar ISO Berbasis Web Dengan Metode Object Oriented
}

\author{
Bambang priyanto (10018039)1, , Tedy Setiadi $(60030475)^{2}$ \\ Teknik Informatika Universitas Ahmad Dahlan, Jl. Ringroad Selatan, Bantul, Yogyakarta 55191, Indonesia \\ ${ }^{1}$ bambangpriyanto2727@ gmail.com; ${ }^{2}$ tedy.setiadi@tif.uad.ac.id
}

\begin{abstract}
ABSTRAK
Buku ISO Indonesia (Informasi Spesialis Obat) yang memuat banyak nama-nama obat, pabrik yang memproduksinya, jenis-jenis obat, kandungan obat, kategori obat, indikasi, efek samping, cara pakai, dan harga obat. Bisa dibilang ISO ini merupakan kamus bagi orang farmasi. Semua kalangan farmasi mulai dari siswa SAA (Sekolah Asisten Apoteker).kendala pada sistem yang digunakan yaitu belum terdapat cara pencarian obat dengan kandungan yang sama namun berbeda merk, karena pada kasus seperti ini sangat dibutuhkan saat resep obat yang di inginkan tidak ada masih ada solusi digantikan dengan obat merk lain yang tentu mempunyai kandungan obat yang sama. dari hal tersebut dibuatnya sistem informasi obat untuk apotek untuk memudahkan kinerja karyawan, sistem informasi yang dibuat menggunakan basis web untuk memudahkan dalam pengaksesan dalam pengembangan sistem informasi ini diperlukanya framework(CI) untuk pengaplikasianya dan untuk metode ini menggunakan metode object oriented.

Penelitian ini yang menjadi subjek adalah sistem informasi untuk mengolah data obat dan transaksi pada apotek. Metode yang digunakan dalam menyelesaikan tugas akhir ini adalah mengamati langsung proses transaksi dan pembuatan laporan, pengumpulan data yang meliputi data obat, data golongan ,data kategori dan laporan transaksi, analisis sistem baik kebutuhan fungsional maupun nonfungsional dalam system informasi obat, serta pengembangan sistem yang meliputi perancangan sistem dengan memberikan informasi obat berdasar ISO menggunakan media internet berbasis web, implementasi sistem informasi berfokus pada pencarian obat untuk mendapat solusi penggantian obat ketika obat yang di cari tidak ada akan digantikan dengan obat lain yang mempunyai kandungan sama, pengujian sistem ini menggunakan metode Black Box Test dan Alpha Test.

Penelitian yang dilakukan menghasilkan sebuah sistem informasi obat berdasar ISO berbasis web dengan metode object oriented dengan hasil pengujian sistem yang diterapkanya kamus ISO dapat memberikan alternative pemilihan obat ketika stok tidak tersedia akan di sarankan obat lain yang tentu mempunyai kandungan yang sama dengan obat yang di maksud, Kamus ISO yang dilengkapi dengan indeks abjad yang terurut akan mempercepat pencarian obat ,Serta dapat membuat laporan transaksi jual beli obat dengan cepat dan memberikan data laporan dari hasil transaksi yang akurat serta dapat memberikan informasi kepada apoteker tentang status obat atau kadaluarsa obat
\end{abstract}

Kata kunci: ISO, Framework(CI), object oriented 


\section{Latar Belakang}

Farmasi merupakan salah satu ilmu pengetahuan yang sangat membantu kebutuhan di masyarakat luas. Oleh karena itu dibutuhkanya daya ingat yang kuat untuk menghafal jutaan nama-nama obat, kandungan-kandungannya, serta kegunaan dari obat-obat tersebut. Namun otak manusia ada batasnya juga, tidak semua obat-obatan dapat diingat dengan baik. Untuk itulah IAI (Ikatan Apoteker Indonesia) menerbitkan buku ISO Indonesia (Informasi Spesialite Obat Indonesia). Dari analisa tersebut maka dibutuhkanya sistem informasi yang terkomputerisasi dengan menerapkan kamus ISO didalam sistem untuk memudahkanya pencarian nama obat secara cepat dan akurat.

\subsection{Identifikasi Masalah}

- Pencarian daftar obat pada apotek hanya sebatas katalog yang befungsi untuk mencari nama obat, kandungan obat.

- Sistem yang digunakan belum tersedianya status obat atau kadaluarsa obat.

Sistem yang ada belum bisa menampilkan merk obat dengan kandungan yang sama dengan obat merk lain ketika obat yang di maksut tidak tersedia.

\subsection{Batasan masalah}

- Pengujian hanya berfokus pada pencarian obat yang membandingkan obat merk satu dan merk lain yang mempunyai kandungan obat sama.

- Data obat yang digunakan hanya bersumber dari buku ISO.

- Tidak sampai pada data-data keuangan.

\subsection{Rumusan Masalah}

Berdasar latar belakang yang telah disampaikan sebelumnya, maka dapat menarik masalah, bagaimana mengembangkan Sistem Informasi Spesialite Obat Indonesia (ISO) agar bisa diterapkan pada data yang terkomputerisasi dengan media internet yang bebasis Web sehingga dapat mempermudah dan mempercepat pekerjaan karyawan dalam pencarian obat.

\subsection{Tujuan Penelitian}

Menerapkan ISO (informasi spesialis obat) ke sistem yang terkomputerisasi untuk mempermudah kinerja karyawan Apotek untuk mencari nama-nama obat dan kandungannya ketika resep yang dicari tidak ada akan diganti dengan obat lain yang kandunganya sama dan tersedia pada apotek.

\section{Landasan Teori}

\subsection{Sistem Informasi}

Kadir (2014) Menyatakan bahwa Sistem Informasi adalah sebuah sistem yang dibuat yang bertujuan untuk menghasilkan sebuah informasi. Menyatakan bahwa Pengembangan sistem berarti menyusun suatu sistem yang baru untuk menggantikan sistem yang lama secara keseluruhan atau memperbaiki sistem yang telah ada.Pengembangan sistem informasi merupakan tindakan mengubah, menggantikan, atau menyusun sistem informasi, baik secara keseluruhan maupun sebagian untuk memperbaiki sistem lama agar menjadi lebih baik.

\subsection{ISO (Informasi Spesialite Obat) Indonesia}

ISFI (2009) Menyatakan bahwa Buku ISO Indonesia dibuat dan disusun oleh ISFI (Ikatan Sarjana Farmasi Indonesia) merupakan "kamus obat" yang harus dimiliki oleh setiap keluarga bahkan setiap orang yang merasa perlu tahu lebih jauh mengenai obat-obat apa yang beredar saat ini. Buku ini terlebih wajib harus dimiliki oleh para kalangan farmasi.Mulai dari pelajar, mahasiswa, hingga profesi setingkat professor. Buku ISO Indonesia ini selelu diperbaharui dan terbit tiap tahunnya. Dan tiap kali terbit, jenisjenis obat yang ada dalam buku ini pun bertambah. Hal itu dikarenakan telah ditemukannya obat-obatan terbaru dalam jangka waktu satu tahun tersebut.Terakhir buku ini sudah mencapai volume 46 yang terbit di tahun 2011. Selain dari daftar isi, data obat-obatan dikelompokkan juga per-jenis pengobatan. Serta 
terdapat pula indeks nama obat, sehingga memudahkan penggunanya dalam pencarian. Dalam setiap keterangan obatnya, dicantumkan kandungan bahan, dan kegunaan obat, serta beragam informasi bermanfaat lainnya termasuk indikasi, kategori, hingga harga pasarannya. Dari hal itulah buku ISO ini sangat diperlukan di kalangan apotek-apotek untuk pedoman ketika apoteker tidak tau apa fungsi dan kegunaan obat. Dari buku ini mereka dapat mengetahui semua penjelasan tentang obat yang di cari.

\subsection{Basis Data}

Prihantara ( 2012) Menyatakan bahwa basis data ialah kumpulan data yang saling berhubungan yang disimpan secara bersama sedemikian rupa tanpa ada pengulangan (redundancy) yang tidak perlu, untuk memenuhi kebutuhan.

\subsection{Sistem Basis Data}

Kadir (2014) Menyatakan bahwa sistem basis data ialah suatu sistem yang disusun dan dikelola untuk mengolah data menggunakan komputer dan disimpan untuk memelihara data sebuah organisasi atau perusahaan sehingga informasi yang disajikan dapat maksimal dan dapat dipakai user dalam mengambil keputusan.

\subsection{Use-Cace}

Mauluddin (2011) menyatakan bahwa :

- Diagram use case merupakan pemodelan untuk menggambarkan kelakuan (behavior) sistem yang akan dibuat.

- Diagram use case mendeskripsikan sebuah interaksi antara satu atau lebih aktor dengan sistem yang akan dibuat.

- Diagram use case digunakan untuk mengetahui fungsi apa saja yang ada di dalam sebuah sistem dan siapa saja yang berhak menggunakan fungsi-fungsi tersebut. Yang ditekankan pada diagram ini adalah "apa" yang diperbuat sistem, dan bukan "bagaimana".

- Sebuah use case merepresentasikan sebuah interaksi antara aktor (user atau sistem lainya) dengan sistem.

Use case menjelaskan secara sederhana fungsi sistem dari sudut pandang user.

\subsection{Activity Diagram}

Prihantara ( 2012) Activity Diagram adalah diagram yang menggambarkan worlflow (aliran kerja) atau aktivitas dari sebuah sistem atau proses bisnis. Yang perlu diperhatikan adalah bahwa diagram aktivitas menggambarkan aktivitas sistem bukan apa yang dilakukan aktor, jadi aktivitas yang dapat dilakukan oleh sistem.

\subsection{Class Diagram}

Nuryanto (2015) Class diagram adalah diagram yang menggambarkan struktur sistem dari segi pendefinisian kelas-kelas yang akan dibuat untuk membangun sistem. kelas memiliki 3 bagian utama yaitu attribute, operation, dan name. kelas-kelas yang ada pada struktur sistem harus dapat melakukan fungsi-fungsi sesuai dengan kebutuhan sistem.

\section{Subjek Penelitian}

Subjek penelitian yang akan dibahas adalah pengembangan sistem informasi apotek berbasis web yang menggunakan kamus ISO (informasi spesialis obat). Sistem informasi yang dibuat diharapkan bisa meningkatkan efektifitas dan efesiensi pelayanan untuk konsumen dengan membuat mesin pencari data obat pada apotek selain itu juga diharapkan dapat mempermudah apoteker untuk masalah pembuatan laporan transaksi jual beli pada apoteker di masa mendatang. 


\subsection{Alat Penelitian}

Dalam melakukan penelitian ini memerlukan beberapa peralatan yaitu: perangkat keras(hardware) dan perangkat lunak(software). Untuk perangkat lunak meliputi sistem operasi dan berbagai aplikasi lainnya. Namun untuk perangkat keras meliputi perangkat-perangkat kompter pada umumnya.

\subsection{Pengumpulan Data}

a. Observasi

Metode ini dilakukan dengan berkunjung langsung ke Apotek wonosari yang dijadikan sampel penelitian untuk mendapatkan gambaran serta data-data yang dibutuhkan selama penelitian berlangsung, serta melakukan pengamatan terhadap sistem pelayanan yang sudah berjalan saat ini secara cermat dan sistemastis.

b. Wawancara

Merupakan metode yang dilakukan dengan mengadakan Tanya jawab secara langsung dengan sumbersumber yang dipercaya yang terkait dengan topik penelitian, agar memperoleh data yang lebih akurat dan lebih spesifik. Dalam kasus ini berfokus pada Bidang sistem informasi yang digunakan dan kendala yang dihadapi.

c. Studi Pustaka

Merupakan metode yang dilakukan dengan membaca literatur berupa buku, makalah, artikel, jurnal, skripsi serta mempelajari beberapa data yang ada di internet yang berkaitan dengan sistem informasi mengenai apotek.

\subsection{Analisis Sistem}

a. Analisis Data

Analisa data dilakukan dengan cara mengklasifikasikan data yang berfungsi untuk mengelompokkan data yang sesuai dengan jenisnya untuk mendapatkan data yang valid pada saat pencarian dilakukan.

b. Analisis Kebutuhan pengguna

Mencermati segala kebutuhan dari apoteker dan pemilik apotek untuk mencapai tujuan dari sistem yang dibuat.

c. Analisis kebutuhan fungsional

Mencermati pengoprasian sistem oleh user untuk Mengetahui fungsi sistem dilakukan dengan cara menyeleksi fungsi-fungsi yang dibutuhkan.

d. Analisis kebutuhan non fungsional

Mencermati pengoprasian sistem oleh user untuk mengetahui fungsi sistem apa saja yang tidak diperlukan.

\subsection{Perancangan Sistem}

a. Perancangan Basis Data

Perancangan Basis Data digunakan untuk pendefinisian tabel-tabel yang diperlukan untuk pengembangan. Yang mana setiap tabel memiliki relasi (hubungan) dengan tabel yang lainnya

b. Perancangan antar muka (User Interface)

Merancang tampilan dan tata letak fitur aplikasi agar memberikan kemudahan pengguna dalam menggunakan dan mengakses setiap menu yang ada. Perancangan antar muka menggunakan Desain antarmuka sistem server. Berisi rancangan antarmuka web yang akan digunakan admin di sistem server.

\subsection{Implementasi}

Setelah tahap perancangan sistem, maka tahap selanjutnya yang dilakukan adalah mengimplementasikan rancangan sistem tersebut menjadi sebuah aplikasi. Sistem ini diimplementasikan dengan bahasa pemrograman php dan menggunakan database MySql 


\subsection{Pengujian Sistem}

Setelah program selesai dibuat maka tahap berikutnya adalah uji coba terhadap sistem yang telah dibuat tersebut, untuk memastikan apakah sistem yang dibangun dapat berjalan dengan baik atau tidak menggunakan metode:

\section{a. Black Box Test}

Merupakan pengujian sistem yang dilakukan dengan mengamati kesinambungan antara masukan dan keluaran dengan meminta responden untuk memberikan penilaian. Responden yang melakukan tes uji sistem ini dilakukan oleh administrator yang bersangkutan.

\section{b. Alpha Test}

Pengujian Alpha Test adalah pengujian sistem yang dilakukan oleh para pemakai (user) sehingga dapat diperoleh tanggapan dari pemakai tentang program tersebut, baik dari segi format, tampilan maupun tingkat keramahan programnya. Pengujian ini dilakukan oleh orang yang terkait yaitu Pemilik Apotek, Karyawan Apotek.

\subsection{Hasil Pengumpulan data}

Gambaran umum dari sistem informasi yang telah dibuat untuk apotek diharapkan agar dapat mempermudah dalam proses pengolahan data sehingga mempermudah pekerjaan. Dengan adanya sistem informasi ini, admin dapat dengan mudah mendapatkan data-data obat yaitu nama obat, kandungan obat, kategori obat, waktu kadaluarsa obat, dan memudahkannya apoteker merekap laporan antara lain laporan penjualan, pembelian, stok obat dan laporan kadaluarsa obat sehingga tujuan diciptakan sistem informasi ini dapat terwujud seiring berjalannya waktu dan menghasilkan sistem yang sesuai dengan di inginkan.

Pembuatan sistem informasi ini dilakukan dengan menggunakan waterfall model yang terdiri dari beberapa tahapan seperti analisis, desain, perancangan, implementasi, dan perawatan.

\section{Analisis Sistem}

Mencermati segala kebutuhan dari pengguna untuk mencapai tujuan dari sistem yang dibuat berdasarkan hasil metode pengumpulan data yang telah dilakukan maka dapat disimpulkan kebutuhan user adalah apoteker dan pemilik yang akan digunakan dalam sistem informasi berdasar ISO di apotek Wonosari Gunungkidul.

\subsection{Perancangan Sistem}

\section{- Use-Case}

Berdasarkan fitu-fitur dalam rancangan sistem informasi berdasar iso yang telah dibuat pada tahap sebelumnya, maka dapat digambarkan use-case diagram sistem gambar berikut:

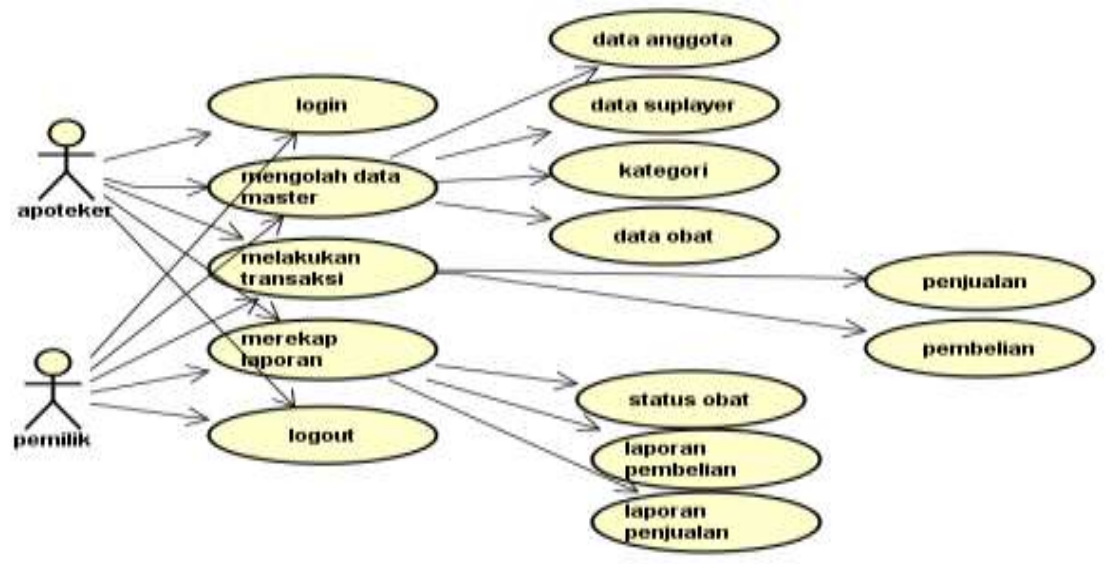


Gambar 1 Use case sistem informasi.

Dari gambar diatas dapat dijelaskan sebagai berikut:

1. Sistem memiliki 2 aktor yang berhubungan dengan fungsi-fungsi sistem, yaitu apoteker dan pemilik apotek. apoteker memiliki autentifikasi dan hak akses penuh dari sistem informasi. Dan pemilik apotek sama halnya memiliki hak akses penuh dari system informasi .

2. Sistem aplikasi ini memiliki 10 fungsi yang dapat diakses oleh seorang administrator antara lain sebagai berikut:
a) Fungsi Login
b) Fungsi data obat
c) Fungsi penjualan
d) Fungsi pembelian
e) Fungsi laporan
f) Fungsi suplayer
g) Fungsi data anggota
h) Fungsi status obat/kadaluarsa
i) Fungsi logout

\section{- Activity Diagram}

Activity diagram menggambarkan alur kegiatan dari suatu fungsi dalam sistem. Dalam sistem ini terdapat salah satu fungsi pencarian yang menerapan ISO dalam sistem.

Activity diagram ini menggambarkan bagaimana proses pencarian data obat berdasar ISO untuk mengetahui kandungan obat yang sama ketika nama obat yang di cari tidak tersedia dengan obat merk lain seperti gambar

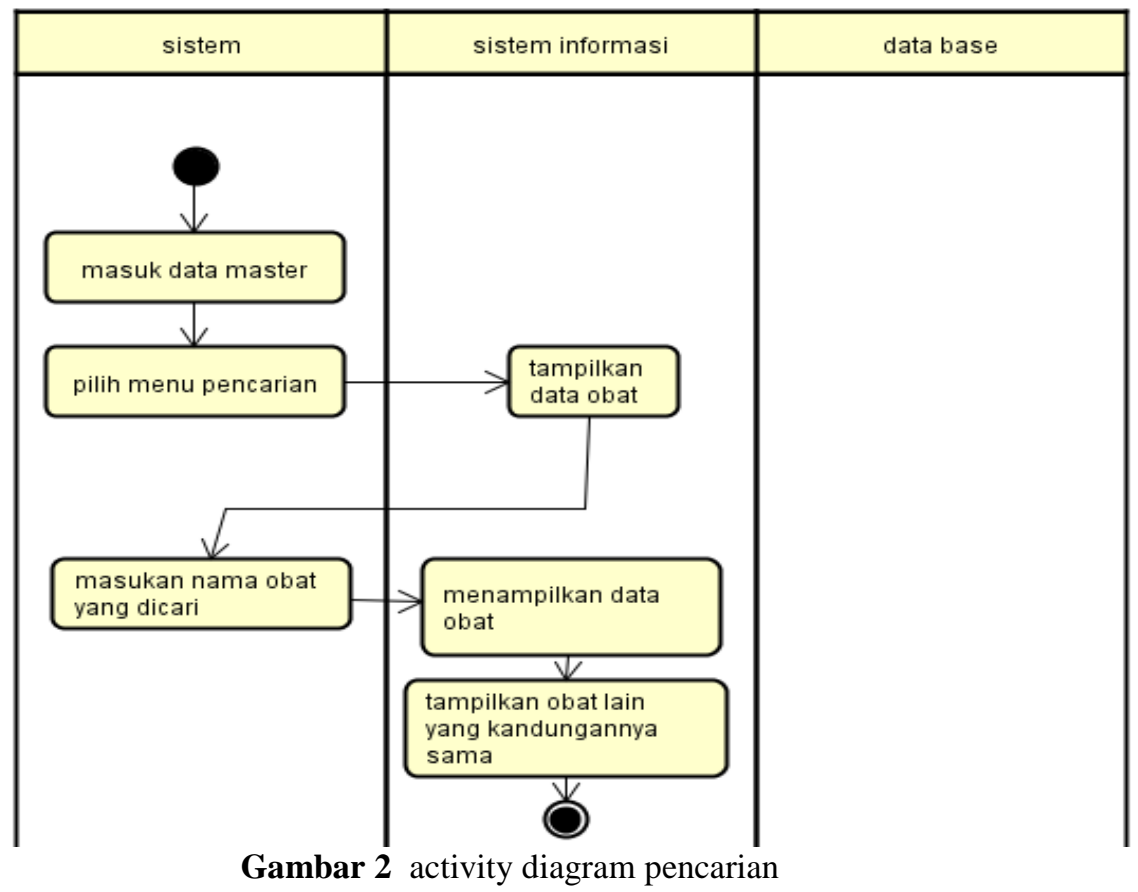

- Class-Diagram 


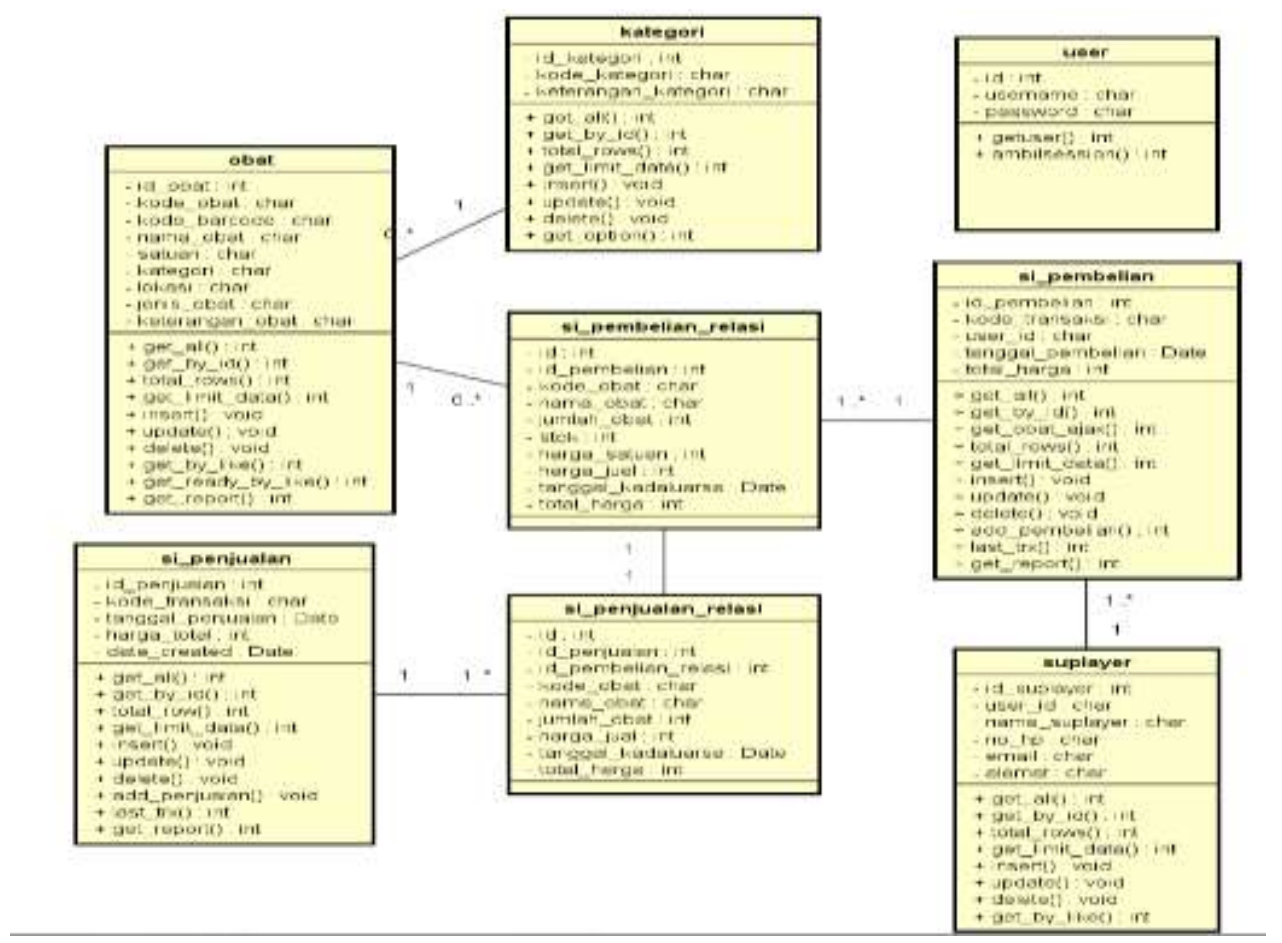

Gambar 3: class-diagram objek dari sistem informasi obat

Dalam class-diagram yang terbentuk, terdapat 8 kelas objek. Masing-masing kelas objek akan direpresentasikan dalam bahasa web programming yang berhubungan dengan database atau entitas. Masing-masing kelas memiliki metode tersendiri sesuai dengan kebutuhan sistem ada yang hanya bisa dibaca dan ada juga yang bisa di baca dan tulis. data ini bersifat public namun tidak dapat diakses kecuali oleh pihak yang mempunyai hak akses. Di dalam kelas kontroler tersebut terdapat beberapa metode. Berikut metode yang dimiliki kelas controller admin:
a. Login
b. Mengolah data obat
c. Mengolah data kategori
d. Mengolah data suplayer
e. Mengolah data anggota
f. Mengolah data penjualan
g. Mengolah data pembelian
h. Merekap laporan dan cetak laporan
i. Logout

\section{Implementasi}

\section{Tampilan Beranda}

Pada tampilan beranda ini merupakan tampilan awal ketika apoteker berhasil login ke sistem dengan tampilan seperti gambar berikut : 

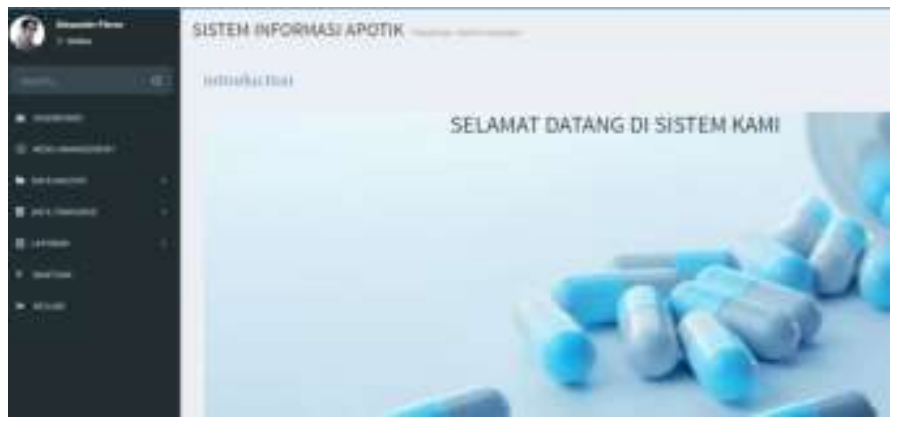

\section{Tampilan input data obat}

Halaman ini merupakan tampilan input data obat ketika pengguna masuk ke menu data obat, halaman ini digunakan untuk menambah data obat baru atau mengedit data obat lama dengan tampilan seperti gambar berikut :

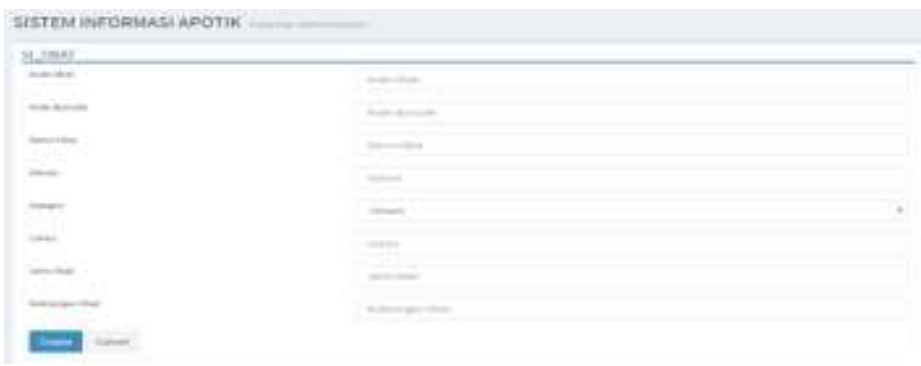

\section{Tampilan menu pencarian}

Halaman ini merupakan tampilan input nama dan kode obat yang ingin dicari oleh pengguna dengan tampilan seperti gambar berikut :

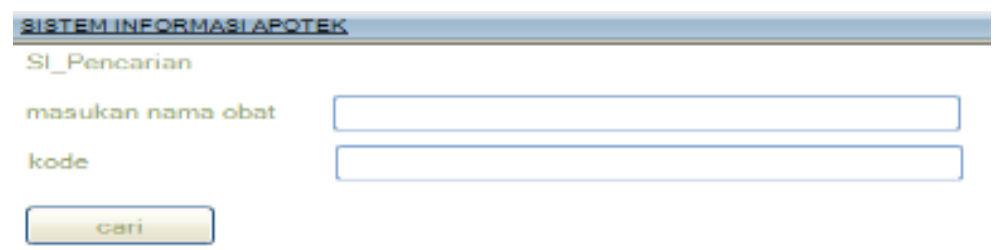

Halaman ini merupakan tampilan output data obat yang dicari dan alternative obat lain yang mempunyai kandungan sama.

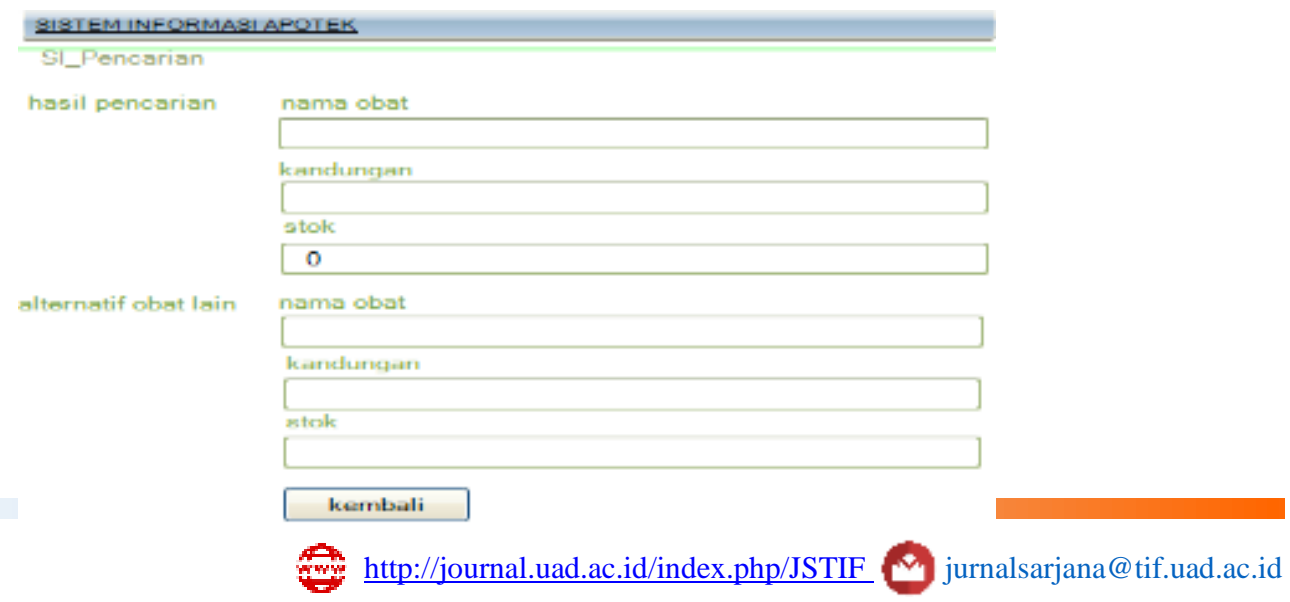




\section{Kemampuan Sistem}

Dengan diterapkanya Sistem berdasarkan ISO (informasi spesialis obat) yang dibuat dan dikembangkan sistem mempunyai kemampuan untu data obat yang lebih cepat terlebih pada funsi pencarian yang mampu untuk mencari nama obat yang di inginkan dan menggantikan obat tersebut dengan obat merek lain dengan kandungan sama pada saat obat yang di cari tidak tersedia.

\section{Kesimpulan}

Setelah melakukan penelitian sistem informasi obat berdasar iso berbasis web dengan metode object oriented di apotek yang terletak di wonosari gunungkidul dapat disimpulkan bahwa :

Telah dibangun sistem informasi obat berdasar iso berbasis web dengan metode object oriented, sistem yang dihasilkan mampu digunakan untuk melakukan transaksi jual beli yang diakses dengan mudah dan cepat.

1. Sistem informasi ini mempermudah dalam pembuatan laporan keuangan baik harian, bulanan dan tahunan yang ada di apotek Wonosari Gunungkidul.

2. Dengan adanya ini dapat menyampaikan informasi dan mengingatkan akan status obat kepada pengguna system di apotek Wonosari Gunungkidul dengan cepat secara otomatis.

Beberapa saran yang dapat diberikan untuk pengembang sistem informasi ini lebih lanjut antara lain sebagai berikut :

1. Melihat keuntungan yang didapat dari adanya sistem informasi obat khususnya dalam input data transaksi penjualan, pembelian dan perekapan laporan yang sangat mudah cepat dan akurat. Ada baiknya jika sistem ini diperluas lagi untuk dapat di akses melalui android. Dengan harapan admin lebih mudah untuk merekap laporan dari mana saja.

2. Mengembangkan system penjualan dengan cara yang lebih praktis sehingga pengguna lebih cepat dalam penginputan data pada saat melakukan transaksi.

\section{Daftar Pustaka}

Abdul Kadir. 2014. Pengenalan Sistem Informasi, Yogyakarta.

Aditia Prihantara. 2012. Sistem Informasi Apotek Dengan Media Katalog Denga Metode Searching.

Agussalim. 2012. Sistem Informasi Penjualan Obat Pada Apotek Rumah Sakit U'budayah Indonesia Menggunakan Visual Basic 6.0.

Bagus Ardy. 2013. Sistem Informasi Persediaan Obat Pada Apotek Patra Farma, Jepara.

Dian Gustina, Achmad Sumbaryadi, Andri Nuryanto. 2015. Rancang Bangun Sistem Informasi Managemen Persediaan Obat Pada Apotek Kimia Farma.

Hendra. 2015. Perancangan Aplikasi Pengelolaan Apotek Dan Pengobatan Yang Terintegrasi Di Aapotek Vika . Teknik Informatika UNIKOM, Bandung.

ISFI, ISO. 2009. (Informasi Spesialite Obat) Indonesia, PT. ISFI, Jakarta. 
Nurdiansyah, Ramadian Agus. 2012. Pembuatan Sistem Informasi Apotek Berbasis Web Pada Apotek Tulakan.

Sidik, Betha. 2012. Framework Codelgneter, Informatika Bandung, Bandung.

Syahrul Mauluddin. 2011. Jurnal Program Studi Sistem Informasi, Fakultas Teknik dan Ilmu Komputer Universitas Komputer Indonesia, Bandung.

Tutik Winarni, M3104045. 2007. Sistem Iinformasi Stok Obat Apotek, Program Ilmu Komputer Alam Universitas Sebelas Maret Surakarta.

Yeremia Yuliawan M.J., Dewiyani Sunarto, Tony Soebijono .2007. Pengembangan Sistem Informasi Pendataan Berbasis Web Program Studi/Jurusan Sistem Informasi STMIK STIKOM , Surabaya, 60298. 